\title{
Cultural Analysis, Cultural Studies, and the Situation of Legal Scholarship
}

\author{
Austin Sarat and Jonathan Simon
}

\begin{abstract}
Eerywhere, it seems, culture is in ascendance. More and more social groups - are claiming to have distinctive cultures and are demanding recognition of their cultural distinctiveness. Identity politics has merged with cultural politics so that to have an identity one must now also have a culture. ${ }^{1}$ As a result, it sometimes seems as if almost every ethnic, religious, or social group seeks to have its "culture" recognized, and for precisely this reason the cultural itself has become a subject of political life to a greater extent than in the past.
\end{abstract}

\section{The Death of the Social and the Turn to Culture}

The backlash against the proliferation of cultures and identities, and what is called the "politics of recognition," "culture wars" in an effort to reassert both the meaning and centrality of certain allegedly transcendent human values. ${ }^{3}$ Debates about the meaning and significance of culture become arguments about "civilization" itself, in which acknowledgment of cultural pluralism and its accompanying decanonization of the "sacred" texts of the Western tradition is treated as undermining national unity, national purpose, and the meaning of being "American." ${ }^{\prime 4}$ Political contests are increasingly fought over values and symbols, with different parties advancing different cultural programs. ${ }^{5}$

With the decline of ideology as an organizing force in international relations, culture seems to provide another vantage point from which to understand new polarities. ${ }^{6}$ In addition, the cache of the cultural is increasingly resonant in 
public policy where traditional goals like reducing crime and poverty are giving way to cultural goals like reducing fear of crime and eliminating the culture of dependency. The cultural is the implicit and explicit space of intervention for popular new strategies like "community policing" and "workfare"s that promise to improve objective problems by altering the attitudes and experiences of the subjects of policing and welfare. Government and other formal organizations believe that it is essential to have cultural strategies in order to more effectively govern their employees and customers and to influence their broader popular image. The twentieth century familiarized us with the idea of propaganda and the fact that political forces had to utilize mass communications to realize their power. Today, however, the cultural has become more than a supplement or a delivery vehicle; it is quite literally where the action is. ${ }^{9}$

In the academy, sociologists, political scientists, and lawyers today find themselves invoking "culture" more often at the expense of, and in response to, a sense of emergent crisis, with their own master references like "the social," "public opinion," and "law." The cultural, in short, comes as a stand-in for interpretive grids that can no longer be effectively utilized. It is also emerging in the current retail boom in the United States, where the commodity nature of goods is increasingly acknowledged and marketed as such. ${ }^{10}$ Indeed, Etienne Balibar has suggested that "culturalism" is a central logic of late capitalism. ${ }^{11}$

This turn to culture is but one sign of the decline of the social as central to the logic of governance throughout societies of the West. By "the social," we mean to invoke the conviction, so widely held in the West since the Renaissance, that the collective character of human populations determines history in ways not reducible to external factors like religion, sovereignty, or climate; we also mean to invoke the incredibly diverse range of discourses and forms of expertise that have occupied this field ever since. Some scholars now speak of the "death of the social."12 One need not endorse so dramatic a view to acknowledge that the social in this historically specific sense faces increasing competition and challenges to its legitimacy. This decline comes after the end of a period that reached its peak in I960s and 1970s, when governments in the advanced industrial societies sought to self-consciously govern through the social, a strategy sometimes described as "the social welfare state" or the "social activist state." During that period, the liberal rationality of government associated with laissez-faire and methodological individualism was generally reordered around the social as a terrain of positive knowledge and for effective governmental intervention. Thus social liberalism produced a powerful fusion of law, social science, and government. 
However, after decades in which social problems, poverty, labor exploitation, and crime, for example, set the agenda of government, the social itself has come to be defined as a problem to be solved by reconfiguring government. ${ }^{13}$ The general decline in confidence in virtually every institution and program of reform, or knowledge gathering, attached to the social is one of the most striking features of our present situation. Social work, social insurance, social policy, and social justice, once expected to be engines of building a more rational and modern society, are today seen as ineffectual and incoherent. Socialism, once taken to be a very real competitor with liberalism as a program of modern governance, has virtually disappeared from the field of contemporary politics. Whereas the social sciences-and especially sociology (the most social)-had become court sciences at the highest levels in the I960s and I970s, they are today largely absent from national government and are experiencing their own internal drift and discontent.

The United States, where both authors live and work, clearly represents the extreme case of the problematization of the social. The most florid forms of the social, such as social insurance, public transportation and housing, public health and social medicine, as well as socialism, were never as actively embraced by American state or federal governments as they were in comparably industrialized societies in Europe, Japan, Australia, and the Americas. Moreover, in no society was the political critique of the social as successful as it was in the United States under presidents like Ronald Reagan, George Bush I, and Bill Clinton. It is clear, however, that the crisis of the social is being experienced globally today, not only in the formerly welfarist Western nations but also in those states now industrializing. Where the social survives more intact than in the United States, one might expect to find the intellectual trends we describe here less well entrenched and more resisted.

Traditionally, law has had an important set of relationships to the state through the complex mechanisms of sovereignty, but in the twentieth century law became not just an expertise about sovereignty but also an expertise about governance, a currency that brought law into competition and collaboration with the social sciences. The social sciences likewise established themselves as important adjuncts to governance in part through the mediation of law land to a lesser degree medicine), including criminology, social work, and public health, and later every aspect of economic and general policy. ${ }^{14}$ Legal studies ${ }^{15}$ never collapsed into pure policy studies, whatever the ambitions of some may have been, but to a great extent its critical efficacy came from its relationships with governance. ${ }^{16}$ 
In making these claims, we do not mean to raise anxieties about the closeness of knowledge and power; indeed, in the tradition of Foucault, we want to call attention to precisely how productive this relationship has often been. ${ }^{17}$ Regardless of whether legal scholars imagine themselves as allies or critics of the policy apparatus, the practices of governance help set the agenda for legal scholarship. ${ }^{18}$ Indeed, for legal scholarship to do its job, it must respond to changes in practices of governance by realigning its scholarly practices and knowledge paradigms. Thus one thing that is at stake in the movement from society to culture as a way of organizing social relations is the need for a realignment of scholarly practices, making way for a more prominent and productive engagement among cultural analysis, cultural studies, and law. ${ }^{19}$

Although it would take a book of its own to describe transformations in the field of legal studies associated with the decline of the social as a nexus of governing, evidence abounds that the shifting engagement between legal studies and government has altered the formation and deployment of legal knowledge at all levels. Consider how much of modern constitutional theory and jurisprudence has been a response to the expansion of the social liberal state. Likewise, the prestige of empirical research has been tied up with the access that social and legal scholars obtained as experimenters and expert consultants helping to administer a state engaged in interventions in problems like crime, gangs, and urban poverty. Even those discourses that have offered a more critical view of the enterprise of social policy and social research have often promoted both policy and research by exposing the gaps in action and imagination created by racism, patriarchy, and class privilege..$^{20}$

Our interest here is to explore the implication of changing logics of governance for interdisciplinary legal scholarship. ${ }^{21}$ Our claim is quite simple: namely, that as the logics of governance in the late modern era turn from society to culture, legal scholarship itself should turn to culture and more fully embrace cultural analysis and cultural studies. We see cultural analysis and cultural studies more as valuable supplements for the altered environment of the present than as competitors to the multitude of intellectual programs that already operate in what might be called the postrealist legal landscape, including varieties of realism, its moderate legal-process critics, as well as the more radical recent critical discourses including law and economics, critical legal studies, feminism, and critical race theory. Rather than as another interdisciplinary project to be added to the array of such projects, we view cultural studies as a kind of epistemological corrective to the plethora of problems posed for postrealist legal studies by the crises of the social liberal state and its allied forms of knowledge. ${ }^{22}$ 
It should be noted that these problems are not predominantly those of methodology. There has been, of late, a fair amount of worrying about the state of methodologies within legal studies. Such worrying is unsurprising. In their original attack on doctrinalism, legal studies scholars often raised the weapon of the superiority of their methodology. The rise of legal studies methodologies rooted in the humanities inevitably raises questions of turf and rights to speak. In our view, however, the methodological wars between doctrinalists and empiricists throughout the twentieth century reflected the enormous stakes for law, lawyers, and scholars in the social as a rationality of governance. The social, as such, has no methodology. The battle over methodology is more an effect than a cause of the rise of the social. Likewise, the renewed anxiety about methodology in legal studies since the I 980 s reflects the destabilization of status and role within legal studies brought on by the breakdown of the social as a rationality of governance.

We also see legal studies as providing a crucial site of engagement for the broader movement of cultural analysis and cultural studies. Much of the analytic power of cultural studies in fields like literature and film studies has been to treat these discourses as law-like in being constitutive of the social relations they might otherwise seem only to simply represent. In looking beyond the narrowly juridical to show how novels, newspapers, and soap operas help create the nation as an imaginary community, ${ }^{23}$ cultural studies often reads back into these narratives a model of law that is more rule-like, more coherent, and more functional than that described by legal studies. ${ }^{24}$

The emergent "cultural turn" in legal studies is one we welcome and have sought to participate in. ${ }^{25}$ The cultural that is turned up naturally varies greatly with the knowledge practices of the analysts. Under the banner of privileging the cultural, research strategies have been employed that emphasize listening to the way ordinary people construct the law in their narratives about themselves, ${ }^{26}$ listening to the way judges and law professors construct law in their narratives, ${ }^{27}$ and reading the implicit norms that govern personal choices and behavior, just to name some of the ways it has been invoked. ${ }^{28}$

Looking for ways to build common links among the diverse knowledge strategies associated with the cultural is an important task that needs to continue now that some of the most polemical assumptions about the opposition between rigorous empirical work and the cultural turn have passed. It is time to explore the terrain of possibilities that might be opened up by a greater engagement between cultural analysis, cultural studies, and law. A good place to start is with the relationship between cultural analysis as a competitor to social 
analysis and cultural studies. There is one sense in which cultural studies is itself an example of the ubiquity of cultural analysis, representing as it were the opening up of a specific discipline with the cultural as its subject. In that sense, it might play the part that "sociology" played in the rise of the social, namely, that of being the discipline that articulates the most ambitious scope for knowledge of the social and that simultaneously expresses the vulnerabilities of government founded on the social. Cultural studies is a self-conscious reflection on the conditions of producing knowledge in a postsocial environment-that is, at a time when the forms of knowledge and power that have invested the social with power, truth, and significance are being decomposed and dismantled.

While suspicious of the social, cultural studies is far from being a promoter of cultural knowledge. It has flourished in disciplines like anthropology and literature that have dealt with "culture" as a key term for a long time, and in these disciplines cultural studies has been the banner waved by many of those most concerned with the power effects of cultural knowledge.

Before introducing the essays that make up this volume, we will briefly flesh out our claims about the value of engagement between cultural studies and law. If cultural studies is both a new sociology in the breadth of its claims and an engagement with the conditions of living in a time when the social is waning as a model of governance, it provides a compelling interlocutor for legal studies. We explore this claim by a brief comparison with the project of legal realism, a movement that reflected early on the power of the social for governance and thus the need for a law engaged with the social. The coming together of cultural studies and legal studies has parallels with the rise of legal realism, even as it represents the first true step away from it.

\section{Unpacking the Cultural Baggage of Legal Realism}

With the ascendancy of legal realism during the last two-thirds of the twentieth century, both law and social science found themselves engaged in the practical arts of governing to an extent barely imagined in the preceding century. ${ }^{29}$ As the state came to reconfigure its approach to governing around problems of the social, both law and social science were invested with new resources and roles. Social and legal reform reached a peak in the I960s and I970s, not coincidentally as law and social science were reaching their own peaks of prestige. In the years since, there has been a great deal of internal criticism of the reform effort within both law and social science. ${ }^{30}$ Moreover, the current generation of legal scholars must contend with a cultural programming that is increasingly con- 
straining. ${ }^{31}$ This programming limits the horizons of scholarly inquiry by emphasizing units and forms of analysis that may not be adequate in the face of contemporary social and political developments.

Among the most significant features of this programming are the imaginary boundaries of the social body within which the realist paradigm in both law and social science has been bound. Realist legal studies almost always operates within a political body, usually the nation, although this fact is not usually itself an object of analysis. ${ }^{32}$ The boundaries and exclusions wrapped up in this national frame are made up not just of political borders but also of the racial, cultural, and linguistic embodiments. When a U.S. citizen of Hispanic origin is stopped by customs agents near the Mexican border of California, Arizona, or Texas, there is an evident surplus to their political identity that is neither identical with nor protected by citizenship in the political sense. ${ }^{33} \mathrm{~A}$ similar emphasis on cultural citizenship seems to apply far from the border, or from direct questions of nationality, when African American drivers are pulled over by police almost anywhere along infamous Interstate 95.

Today, scholarship and politics increasingly confront an array of breaches in this imaginary order in the form of globalization, the Internet, identity politics, and the risk society, for which the realist paradigm seems inappropriate. New scholarship has taken up race, space, and the nation as an imaginary community within legal studies; ${ }^{34}$ but so long as this scholarship is treated largely as a new mode of realist discourse, it may continue to have little effect on the great mass of legal thought. ${ }^{35}$ Even when mainstream legal scholarship self-consciously looks beyond the national, the priority remains on those topics and actors of greatest concern to the Western nations, such as copyright protection and trade in goods and services, while the transnational flows of labor, black market profits, and refugees that concern much of the Third World tend to be ignored.

A second of its continuing constraints is the realism of legal realism, that is, its epistemological assumptions about the interpretive value of certain kinds of observations, such as those regarding the behavior of formal legal actors, social forces, and institutions. The first wave of realists entered into an alliance with practitioners of the fledgling social sciences, absorbing a positivist epistemology with its emphasis on counting and statistical analysis, ${ }^{36}$ and this epistemological link has remained remarkably enduring. ${ }^{37}$ Despite its academic success, the realist frame is being strained by transformations in the construction of subjectivity.

Postrealist legal studies, like much of the dominant social science discourse of the post-World War II era, has largely ignored the problem of the 
subject. ${ }^{38}$ This has profound implications for our understandings of power since its exercise always has subjective effects on its targets and observers. These include terror, sexual arousal, admiration, and guilt. Often these are precisely the intended effects, but not infrequently they are also of a sort inconvenient for long-term domination. ${ }^{39}$

Moreover, the absence of interest in subjectivity does not guarantee the absence of an implicit model of the subject that constrains legal analysis; indeed, it practically guarantees that such constraints will show up. The breadth of subjective interest represented in most legal studies extends little beyond the rational actor of law and economics. ${ }^{40}$ Little success has been achieved in making the gendering of this subject visible despite two decades of powerful feminist critiques. Other efforts to describe the "unthought" or "unconscious" parameters of legal studies have hardly begun. In addition, the new economy taking shape around the high technology sector in the United States reflects the tremendously successful cultural revolutions of the I 960 s and I 970 s with their emphasis on personal satisfaction (paradigmatically sexual), intense experiences (once drugs, now expensive trips to Nepal), and forms of interpersonal transcendence (sexual, religious, group process). For legal studies to address these revolutions, and to effectively unpack the place of culture in new logics of governance, it is incumbent on us to consider not only different sites of analysis (poems, novels, letters) but wholly different strategies of relating to different kinds of data.

As we shall detail in the next section, cultural analysis and cultural studies are well suited to aid postrealist legal discourses in accomplishing this task and to foreground the constraints of forms of knowledge production and engagement with governance that have shaped the disciplinary space in which those discourses operate. Since its beginnings in I950s British Marxism, cultural studies, in particular, has long been concerned with the unthought or unconscious mechanisms that underlie the central solidarities of modern societies (nation, race, class position, gender).41 Many of the techniques used by cultural studies to pursue this uncovering, including deconstruction, genealogy, psychoanalysis, Marxist dialectics, and feminism, are already widely familiar in legal studies. Less familiar, however, is the commitment to engage with the cultural imaginary and the unconscious as a factor in law.

Cultural studies has also long been attentive to both the role of subjectivity in history and to the complex interpenetrations of power and subjectivity, ${ }^{42}$ or what Richard Johnson calls "the subjective side of social relations." ${ }^{43}$ Indeed, much of the corpus of cultural studies consists of tools for tracking the produc- 
tion of subject positions as well as of a growing set of "case studies" in the subjective history of power in modern liberal democracies. Beyond methodological innovation, cultural studies can promote change in legal studies by widening the moments of subjectivity that are even considered in the analysis of law and legality. In addition, while there is a growing interest in popular culture in legal studies, it remains occasional and episodic. ${ }^{44}$ Thus while legal scholars writing, for example, on rape or capital punishment regularly turn to Supreme Court opinions on those topics to tease out their cultural logic, few examine the leading contemporary films that have imagined and portrayed these experiences. ${ }^{45}$ Cultural analysis and cultural studies encourage them to do so.

\section{High Risk Contacts}

For many inside legal studies, the crises we have ascribed to the social liberal state and its effects on the production of legal knowledge are experienced as a serious methodological weakening. A perceived decline in original empirical research, for example, is sometime ascribed to hostility toward science and social reform by younger scholars, yet it may be just as much a result of declining social reform activity and its attendant reduction in opportunities for classic empirical "gap" research. Given that sense of malaise, the entreaty to engage further with cultural analysis, let alone cultural studies, will strike many as a dangerous, high risk endeavor. Indeed, because cultural analysis and cultural studies often are identified with a particularly intense form of boundary breaking, a challenge to givens that regularly invokes the transgressive, one might rightly be skeptical about whether a legal studies field that experiences itself as vulnerable in a highly competitive academic universe would welcome the destabilizing agendas and strategies associated with them. To many, taking on cultural analysis and cultural studies seems like accepting an invitation to enter into the intellectual equivalent of a cocktail lounge where they will be exposed to second-hand smoke and perhaps worse. ${ }^{46}$

Various answers can be suggested. As Carol Weisbrod has recently noted, "One relates to the point that law creates the conditions of culture to some degree. Another notes that law, as a cultural product, may have something in common with other cultural products. Still another focuses on the point that while law is to some extent a mandarin text, it is itself a subject of popular culture. ${ }^{\prime 47}$ As these suggestions indicate, a cultural analysis/cultural studies of law not only helps in challenging traditional ideas of culture, it also may help advance new conceptions of law. Among these conceptions are those that call 
us to attend to the possibility that the proliferation of law in film, on television, and in mass market publications has altered and expanded the sphere of legal life itself and to consider law as a world of images whose power is not located primarily in their representation of something exterior to the image, but is found in the image itself. ${ }^{48}$ Just as almost a century ago legal realists helped put the study of law in action on the agenda of legal scholars, so today perhaps a cultural analysis/cultural studies of law will help expand the terrain of learning about law, open up new arenas for the exploration of law's power, for the pursuit of justice around, and perhaps through, law, and for the development of new understandings of the self's relation to the social. But just as the emergence of realism provoked intense anxiety, so too the emergence of cultural analysis and cultural studies arouses its own distinctive concerns.

In understanding those concerns and how to respond to them, it may be helpful to deepen this comparison with legal realism. Like cultural analysis and cultural studies, legal realism is not a single strand of work; rather, it describes several strands with a family resemblance rather than a deep conceptual unity. ${ }^{49}$ And, like cultural analysis and cultural studies, legal realism has been both assimilated and criticized as a moral danger. Both are relatively easy to caricature. The canard about predicting the law by what judges eat for lunch continues to make legal realism seem both extremist and silly decades after most of legal studies adopted the important realist innovations. Likewise such cultural studies icons as Judith Butler, Homi Bhabha, and Andrew Ross are sometimes dismissed as self-inflating dilettantes who use a forceful rhetoric to replace substantive analysis even as new generations of scholars put their insights to productive use. ${ }^{50}$

When we compare the anxieties associated with the cultural turn with those aroused by legal realism, we have in mind those provoked by innovations in the forms of knowledge acknowledged in legal discourse and the place of lawyers in practicing the arts of government. ${ }^{51}$ From this perspective, the main contribution of legal realism was not to introduce a particular body of legal theory into the discursive universe of legal scholars (although it gave rise to multiple and conflicting theoretical expressions) but rather to position legal analysis with respect to new technologies of knowledge (the behavioral sciences) and to new forms of governing (the progressive and later New Deal state). The old legal science not only excluded the new knowledge from the high church of legal analysis (postrealism would do that as well) but purported to ignore its existence as well as the burgeoning administrative law created by the new modes of state power. ${ }^{52}$ Realism as an academic revolution swept away 
these positions even if the establishment that replaced legal science was far more conservative than we associate with realism's vanguards. Cultural analysis and cultural studies may not prove as threatening to the established order as realism was, but their significance lies in the same direction, that is, in positioning legal studies in relation to new technologies of knowledge and power operating in the aftermath of the social liberal state.

\section{Culturalism, Law, and Late Modernity}

If Etienne Balibar is right that the cultural is all over the place, as a privileged source of knowledge, as a crucial level on which to govern effectively, as a commodity in the market, and that culturalism is a dominant logic of late capitalism (and one might easily add to or replace that with late modernity), we should not be surprised that the cultural is already emergent in legal studies. The question under these circumstances is whether in the midst of this cultural turn legal studies can make the status of the cultural a theoretical problem for itself, and whether such an enterprise is critical to gaining an "empirical" understanding of the legal life of late modernity.

As we take on these questions, it is important to recognize that the ascendance of the cultural comes paradoxically at a time when scholars increasingly have begun to contest the concept of culture and recognize its troubling vagueness. Talking about culture at the start of the twenty-first century means venturing into a field where there are almost as many definitions of the term as there are discussions of it, ${ }^{53}$ with arguments about it raging inside as well as outside the academy. ${ }^{54}$ In recent years, as we noted above, these arguments have come to play a progressively more visible role in our national life, and culture wars are also being fought within universities. ${ }^{55}$ There the history, meaning, and utility of culture as a category of analysis in the humanities and social sciences are all up for grabs. ${ }^{56}$ Where once the analysis of culture could neatly be assigned to the disciplines of anthropology or literature, today the study of culture refuses disciplinary cabining and forges new interdisciplinary connections. ${ }^{57}$ Thus we should resist the temptation to treat battles like the "culture wars" over academic curricula and federal arts and museum programming as penumbras of some deeper social conflict: they represent their own very real conflict.

Traditionally, the study of culture was the study of "that complex whole which includes knowledge, belief, art, morals, law, custom, and any other capabilities and habits acquired by man as a member of society." ${ }^{\prime 5}$ This definition, 
in addition to being hopelessly vague and inclusive, treats culture as a thing existing outside ongoing local practices and social relations. In addition, by treating it in terms of "capabilities and habits acquired" by members of society, culture was made into a set of timeless resources to be internalized in the "civilizing" process through which persons were made social. Finally, culture was identified as containing a kind of inclusive integrity, its parts combining into a "whole." This conception of culture still has its defenders and may even be on the rise as a political knowledge. ${ }^{59}$

Today, however, critiques of the traditional, unified, reified, civilizing idea of culture abound within the academy. ${ }^{60}$ It is now indeed almost imperative to write, to quote Lila Abu-Lughod's influential essay, "against culture" ${ }^{\prime \prime 1}$ or, in the face of these critiques, to "forget culture." 62 Thus during the course of a suit filed by the Mashpee Indians of Cape Cod in I977, James Clifford examined the way culture stood up in a context where the very idea of cultural authenticity was on trial. Culture, he said,

was too closely tied to assumptions of organic form and development. In the eighteenth century culture meant simply "a tending toward natural growth." By the end of the nineteenth century the word could be applied not only to gardens and well-developed individuals but to whole societies. ... [T]he term culture retained its bias toward wholeness, continuity, and growth. Indian culture in Mashpee might be made of unexpected everyday elements, but it had in the last analysis to cohere, its elements fitting together like parts of a body. The culture concept accommodates internal diversity and an "organic" division of roles but not sharp contradictions, mutations, or emergences. . . This cornerstone of the anthropological discipline proved to be vulnerable under cross-examination. ${ }^{63}$

Culture, Clifford concluded, is "a deeply compromised idea. . . . Twentiethcentury identities no longer presuppose continuous cultures or traditions." 64 Or, as T. M. Luhrmann has observed, the concept of culture is "more unsettled than it has been for forty years." 65

In this unsettled moment in the life of the concept of culture, efforts are under way to rehabilitate and reform it. In this effort, contemporary cultural studies has played an especially important role. ${ }^{66}$ Cultural studies has had a bracing impact in giving new energy and life to the study of culture, freeing it from its homogenizing and reifying tendencies. It has done so by radically extending what counts in the analysis of culture beyond the realm of "high culture. ${ }^{167}$ It invites study of the quotidian world. Film, advertising, pop art, con- 
temporary music, and other products of "popular culture" have been legitimized as objects of study. ${ }^{68}$

But, in addition to this liberating expansion in the objects of study, cultural studies has also linked the study of culture to questions of social stratification, power, and social conflict. "[C]ultural processes are," as Johnson notes, "intimately linked with social relations, especially with class relations and class formations, with sexual division, with the racial structuring of social relations. .. . [C]ulture involves power and helps produce asymmetries in the abilities of individuals and social groups to define and realize their needs. And . . culture is neither an autonomous nor [an] externally determined field, but a site of social differences and struggles." 69 Thus culture, Johnson continues, can be understood as "historical forms of consciousness or subjectivity, or the subjective forms we live by. ${ }^{\prime 70}$

Law and legal studies are relative latecomers to cultural analysis and cultural studies. ${ }^{71}$ As Robert Post explains,

We have long been accustomed to think of law as something apart. The grand ideals of justice, of impartiality and fairness, have seemed to remove law from the ordinary, disordered paths of life. For this reason efforts to unearth connections between law and culture have appeared vaguely tinged with expose, as though the idol were revealed to have merely human feet. In recent years, with a firmer sense of the encompassing inevitability of culture, the scandal has diminished, and the enterprise of actually tracing the uneasy relationship of law to culture has begun in earnest. ${ }^{72}$

In the last thirty years, however, first with the development of critical legal studies, then with the growth of the law and literature movement, and finally with the growing attention to legal consciousness and legal ideology in sociolegal studies, legal scholars have come to attend to the cultural lives of law. ${ }^{73}$ Fueled in part by Clifford Geertz's description of law as "a distinctive manner of imagining the real, ${ }^{\prime 74}$ they have begun to be attentive to the imaginative life of the law and the way law lives in our imagination. Law, as Geertz suggested, is not "a mere technical add-on to a morally (or immorally) finished society, it is, along of course with a whole range of other cultural realities, . . . an active part of it."75 Treating law as a cultural reality means looking at the material structure of law to see it in play and at play, as signs and symbols, fantasies, and phantasms. $^{76}$

In the tradition of cultural studies, the cultural analysis of law rejects "the dichotomy between agency and structure. . . Treating consciousness as histor- 
ical and situational, cultural analyses also shifts attention to the constitution and operation of social structure in historically specific situations. ${ }^{177}$ It insists on examining the ways that the cultural lives of law contribute to what Johnson calls "asymmetries in the abilities of individuals and social groups to define and realize their needs." ${ }^{\prime 78}$ The cultural study of law connects the symbolic and the material by resisting their dichotomization. As Silbey puts it, "[L]aw does more than reflect or encode what is otherwise normatively constructed; . . law is part of the cultural processes that actively contribute in the composition of social relations." 79 Law is part of the everyday world, contributing powerfully to the apparently "stable, taken-for-granted quality of that world and to the generally shared sense that as things are, so must they be." ${ }^{80}$

Cultural analysis and cultural studies suggest that law operates largely by influencing modes of thought rather than by determining conduct in any specific case. It enters social practices and is, indeed, "imbricated" in them, by shaping consciousness, by making law's concepts and commands seem, if not invisible, perfectly natural and benign. Law is, in this sense, constitutive of culture, and it is "a part of the cultural processes that actively contribute in the composition of social relations." 81

Cultural analysis insists, however, on the significance of agency. We are not merely the inert recipients of law's external pressures, but law's "demands" tend to seem natural and necessary, hardly like demands at all. In this way the cultural lives of law, Peter Fitzpatrick contends, have been central "in the scaffolding of the modern nation-state" with its construction of the rights-bearing subject, imagined social contract, and insistence on boundary and boundedness. ${ }^{82}$ Nonetheless, legal meanings are not invented and communicated in a unidirectional process. Litigants, clients, consumers of culture, and others bring their own understandings to bear; ${ }^{83}$ they deploy and use meanings strategically to advance interests and goals. They press their understandings in and on law and, in so doing, invite adaptation and change in the practices of law. Law thus exists, in the words of Raymond Williams, as a "moving hegemony." 84

The priority of the cultural in late modern societies also raises the salience of law and legal studies. Most social relations are permeated with law. Long before we ever think about going to a courtroom, we encounter landlords and tenants, husbands and wives, barkeeps and hotel guests, roles that already embed a variety of juridical notions. The hypermediated quality of communities established under the conditions of late modern life embeds law at an even more molecular level because the very flesh of community, the bandwidths of the broadcast world, the networks of cable and phone lines known as 
the Internet, are more abstracted from everyday life and come to us already legally processed to a far greater degree. ${ }^{85}$

Law has played, and continues to play, a large role in regulating the terms and conditions of cultural production. ${ }^{86}$ Cultural analysis and cultural studies call on scholars to attend to this role. The regime of copyright, to take a prominent example, has protected and promoted certain kinds of expression and discouraged others; it has tethered the life of signs to the fortunes of capital, and contributed importantly to the linkage of artistic value with ideas of originality, authenticity, and "Ownership of the image." ${ }^{87}$ Through doctrines of "personality rights," law "authors the celebrity" and, in so doing, gives a particular shape to the practices of "popular culture." 88 In such a setting, cultural analysis and cultural studies anchored in literature, cinema, or music must move beyond treating them as metaphors of legality. Novels and newspapers are not only analogous to legal acts; their operation and the way they circulate, with what kinds of limits are placed on them, are questions of law.

The cultural study of law is then important as a way of unpacking what Rosemary Coombe calls "the signifying power of law and law's power over signification." 89 It invites us to acknowledge that legal meaning is found and invented in the variety of locations and practices that comprise culture and that those locations and practices are themselves encapsulated, though always incompletely, in legal forms, regulations, and legal symbols. Thus the interpretive task for the cultural analyst is quite challenging as she seeks to read everyday cultural forms.

Moreover, the boundaries between cultural analysis/cultural studies as a distinct perspective and the cultural study of law are neither fixed nor clear. The essays collected in this book take on the concept of culture in spite of its vagueness and bring together work from within cultural studies and the broader movement to foster a cultural study of law. The book is, however, neither a comprehensive overview of the ways law shapes culture and culture shapes law nor a survey of cultural approaches to law. Instead, it provides a sampling of significant theoretical issues in the cultural analysis of law and illustrates some of those issues in provocative examples of that genre. It is designed as an encouragement in the still tentative efforts to forge a new interdisciplinary synthesis, a cultural studies of law.

What would legal study look like if it were to take on cultural analysis and/or cultural studies as one of its guiding paradigms? How does a cultural study of law enlarge and alter our conception of the way law lives in and through our identities, interpretations, and imaginings? Can the intellectual strategies 
of cultural analysis and cultural studies be disciplined and made serviceable as a vehicle for the analysis of legal phenomena? Can cultural studies be put into productive dialogue with other forms of cultural analysis, or will such dialogue diminish the significance of both as forces in legal scholarship? These are the questions that this collection of essays addresses. Doing so at this point in the development of cultural study and legal study is indeed daunting when the richness and plurality of the former is as great as it has ever been and when legal scholarship is as open as it has ever been to interdisciplinary interests. But, as we have tried to show, the separation of legal study and cultural analysis, in all its variety, is, at this time in the history of the rationalities of governance, increasingly costly. Maintaining it means missing altogether the surfaces to which empirical methods need to be applied for any hope of getting a purchase on the role of law in contemporary society.

This volume seeks to overcome that separation and to elaborate a cultural analysis of legal life. Yet the essays collected here march under no single programmatic banner. Each speaks in its own voice; each brings its own perspective to bear in talking about, or performing, a cultural analysis of law. Together, they exemplify the kinds of contributions that cultural analysis and cultural studies make to interdisciplinary legal study even as they highlight points of contrast between cultural studies and its allied forms of scholarship. Together, they help reposition legal study in response to the death of the social and the rise of culture in the governance of late modern societies.

\section{Approaches to the Cultural Study of Law}

The first section contains four essays that exemplify particular approaches to the cultural study of law. The juxtaposition of their perspectives maps the terrain that cultural analysis/cultural studies might traverse. This section begins with Naomi Mezey's effort to identify the contribution of cultural analysis to legal studies at a time when, as she notes, "culture is everywhere invoked and virtually nowhere explained." She describes the pervasive invocation of culture as a fact of late modern life, calling our attention to the explanations of the shootings at Columbine High School that made reference to a culture of violence or to the fact that the Juvenile Justice Bill debated in a recent Congress would have allowed schools to post copies of the Ten Commandments as a way of combating youth crime. Mezey quotes the critic Adam Gopnik as saying, "Every age has a term to explain things that resist explanation. The Elizabethans had Fate; the Victorians had History; we have Culture." 
In light of the pervasiveness of culture as an explanation for social problems and a strategy of governance, Mezey argues that we need, even at a time in which we recognize its problematic status, to pursue a "cultural interpretation of law." What, Mezey asks, would such an interpretation do? First, it would give culture some definition, however provisional. Culture, in Mezey's view, is any set of signifying practices, shared practices by which "meaning is produced, performed, contested, or transformed." Second, a cultural interpretation requires that we attend to the way law orders meanings as well as to the "slippage" that almost inevitably accompanies its effort to do so. Mezey calls attention to such quotidian practices as the way gay men in California try to "pick up" other gay men by paying their highway tolls or the way wearing Oakland Raider football jackets signifies gang affiliation and to the ways their significations change in the face of legal regulations. Third, a cultural interpretation of law requires what Mezey calls "thick explanation." This involves analysis of the particularized ways cultural practices coincide or collide with law so as to alter the meaning of either or both.

The work of cultural interpretation, Mezey argues, will never have the parsimony of law and economics and will, as a result, struggle to find a place in the legal academy. Yet its complexity is precisely its virtue. And to neglect cultural interpretation in favor of other kinds of scholarship is to shirk our responsibility as scholars to make sense of the pervasiveness of culture as a category through which events in our world are now so frequently described and explained.

A similar sense of the ethical and political imperative of cultural analysis of law informs the next contribution. This essay claims that cultural studies is a preferred style or type of cultural analysis precisely because of its engagement with, and attentiveness to, the political struggles of our era. Toby Miller provides a definition and overview of cultural studies as well as an example of the kind of work Mezey advocates. His example is drawn from a real world struggle in which he was involved, namely, the effort of graduate students to unionize at New York University. Miller uses that example to highlight what happens at the intersection between legal institutions (in this case the National Labor Relations Board) and cultural practices (in this case what he sees as the exploitation of graduate students by research universities|. That example, he says, also reminds us that cultural studies itself signifies an academic "commitment to progressive social change."

Miller's essay contains a genealogy of cultural studies that calls attention to its multigenerational, multinational origins and lays out a series of under- 
standings of culture, some of which serve the needs of social reproduction and others of which, he claims, promote contestation and social transformation. At the heart of the difference in these uses of cultural analysis, Miller contends, is a commitment to "historical materialism." He argues that in facing new rationalities of governance scholars now need to bring together cultural studies and what he calls "critical political economy." The object is to politicize theory and theorize politics. The cultural analysis of law should contribute to an understanding of "the reproduction of culture through structural determinations on subjects versus their own agency, and the method is historical materialism."

Miller shows what such an analysis might look like in his description of the struggles of graduate students at NYU. In a dramatic shift in style, the second part of Miller's essay is both more personal and more "political." It is more personal in detailing his own engagement in the unionization effort. Here, Miller notes the contradictory position of university officials who in the name of maintaining a democratic university oppose the effort to democratically determine whether graduate students wish to collectively bargain under the auspices of a union. He also explores the difficulty of speaking to and through law, in this case the National Labor Relations Board. Throughout, Miller exposes the complicity of the politics of discursive practices and the political economy of university life.

Miller's genealogical and critical narrative, while it exemplifies the kind of work that Mezey seeks to encourage, becomes an (unnamed) object of critique in the essay by Paul Berman. Miller's style of work relies on what Berman, borrowing from Paul Ricoeur, calls the "hermeneutics of suspicion." Such an approach to cultural study seeks to "unmask, demystify, and expose the real from the apparent." It is relentlessly critical, seeing power and domination everywhere. Berman faults such an approach on two grounds. First, it situates the analyst in a superior position to her objects of study. By unmasking ideologies and power dynamics, "the writer may imply that he or she is able to get beyond the mystification and see the situation more accurately than those caught 'within' the system." Second, and more importantly, the hermeneutics of suspicion has, in Berman's view, a "corrosive effect both on our psyches and on society as a whole," leading us to despair of the prospect of social change through law.

Berman advocates "sympathetic reading" that identifies "what is worthwhile in the efforts of people to construct ideas, systems, or principles." He would fault Miller for not being more empathetic toward the university administrators he describes and would also fault the kind of cultural studies Miller 
practices for not telling stories of "beauty, of optimism, and of hope." Moreover, echoing Habermas and the tradition of American constitutional theory since John Hart Ely, Berman makes the case for law as a powerful institutional home for a view of culture that is both dynamic and tolerant. He urges scholars not to turn away from projects of reform and to tell stories that envision law "not merely as an instantiation of embedded power, but as an activity that might have true intellectual, imaginative, ethical, and political value."

Paul Kahn's work is directly critical of Berman's embrace of reform as a touchstone for, or object of, the cultural analysis of law. Such an approach, Kahn contends, treats the study of law as if it were the same as doing law. It exemplifies the powerful pull of law schools on the way law is studied. Law schools, Kahn argues, hold all scholarship to a pragmatic test, evaluating it in terms of its utility for policy. "The modern law school," he says, "lives with this burden of establishing the form of knowledge appropriate to law." Kahn wishes to distance himself from such a conception of what a cultural analysis of law must be.

He also wishes to distance himself from cultural studies as described by Miller, with its emphasis on the popular, on resistant practices, and so forth, and its view of law as a "set of sites of social conflict, and of resources . . f for those involved in such conflict." In contrast, he urges a focus on the top of the legal hierarchy, on the beliefs and self-conceptions of those who produce law. Studying that group reveals, Kahn argues, that the language of law's rule is our dominant language of political legitimacy. The task of cultural analysis should be to offer a "phenomenology of this distinctive American political culture of the rule of law." What is the world that is imagined in that culture? How is that world contested by other symbolic forms?

A cultural analysis of law should depend, Kahn argues, on distanced, disinterested analysis, just as it seeks to promote a conception of freedom in which understanding of the cultural presuppositions that guide our practices is treated as a precondition of informed action. Rather than pursuing projects of reform, cultural analysis should be turned on one's own beliefs. "Bringing cultural study into the heartland of the legal academy is," Kahn concludes, "a way of putting the self at risk" and of making self rather than other the subject of inquiry.

\section{Deploying Law and Legal Ideas in Culture and Society}

The three essays that make up the next section identify moments of coincidence and conflict between legal and cultural practices and chart the signifi- 
cance of these moments when law comes to culture and when culture comes to law. They show that while law may be part of a larger "culture," the latter is not a "system" in which law plays a consistent role across all contexts. Nobody in our culture would mistake a poem for a court's judgment, but neither would a jurisdictional hierarchy place law above or below poetry. Indeed, much of the work involved in producing culture and law lies in managing the boundaries between them, a game played with often ruthless seriousness by judges and lawyers. But, at the same time, law is always already thoroughly and irreversibly infected by the (often dated) cultural content of its own objects. This puts all of the authors in this section in the difficult position of explicating some of the connections between law and culture while working from some other point of contact between the two.

Carol Greenhouse uses the encounter between cultural studies and legal studies to confront the deep cultural connections between law, social science, and post-World War II American liberalism. That type of liberalism is now canonized in the landmark civil rights and civil liberties victories of the I950s and I960s. According to Greenhouse, the social movements of that period, especially the civil rights movement, produced both a "pragmatics" of reform that animated public discourse and a "poetics" of citizenship that helped shape and define a way of imagining America.

What remains of that era are deep but often hidden connections between the reform agenda of postwar liberalism, on the one hand, and ethnography and literature, on the other. These connections were welded together by the force of the civil rights movement. During the I 980 and I 990 , as the public influence of civil rights waned, and the U.S. Congress and the courts turned hostile to the civil rights agenda, the liberal project became more associated with literature, the arts generally, popular culture, and the academy. This new relationship constitutes, for Greenhouse, the cultural conditions of neoliberalism.

Literature and ethnography remain influential ways of imagining the United States as a national community paradoxically made up of autonomous local communities. Novels by African American women shaped directly by participation in the civil rights movement, like Alice Walker and Toni Morrison, have been best-sellers, even as the electorate has unashamedly rejected many of the legislative victories of the civil rights movement. While ethnography is read by a much smaller audience, there is a lively discourse of "community studies" focused very much on the legacy of the civil rights movement, including the fate of the inner city "ghettos" and their successor communities of the very poor and the ethnically or racially marginalized. Both literature and 
ethnography operate in the thrall of the now absent civil rights movement. Thus while many critics of the cultural turn in the American academy see it as an abandonment of engagement with power, Greenhouse shows that it is the unexamined relationship to liberalism, a regime of governmental power now in crisis, that haunts the academy.

Greenhouse offers an internal critique of American ethnography aimed at reestablishing its dialogue with the fading liberalism of the mid-twentieth century and the emerging neoliberalism at the turn of the twenty-first century. At the core of both post-civil rights literature and American ethnography, she contends, is the relationship of the national community, embodied in the federal government and its agencies, and sometimes in the narrators of the texts, to a local community defined as singular and yet quintessentially American. Ethnographic discourse came to be produced in part to make local communities available to the gaze of a federal government whose claims to power presumed direct access to the local..$^{90}$ Ethnography has continued in this mode since the I97os despite the dismantling of much of the liberal governmental project. In its current form, it constitutes a kind of nostalgic program. Greenhouse suggests that if social-legal studies and ethnography more generally are to have a more critical role in the shaping of neoliberal governance, they must revisit their cultural background, reposition themselves with respect to those movements now shaping the cultural life of law, and pursue a new ethnography of American communities, one attentive to postcolonialism, globalization, and transnationalism.

The next essay in this section operates on a similar terrain, exploring law's relationship to its narrative others. Here, the other is science in the late nineteenth century and the first half of the twentieth. While the social sciences taken up in Greenhouse's essay directly competed and cooperated with law in a visible struggle to shape governance, the traces of science that Wai Chee Dimock explores are those of the natural sciences, as they operated in the imaginary of legal academics seeking to define their own status as producers of expertise (academic law). It is this expertise, in part, that helped form the civil rights coalition Greenhouse describes.

Since the nineteenth century (at the latest), those seeking to recast law as a practice and body of knowledge have repeatedly invoked the model of science. Christopher Langdell, dean of Harvard Law School and inventor of the influential "case method," described his goal as moving law from a craft to a science, for which the law library with its collection of judicial opinions would play the same role that the laboratory, the museum of natural history, and the botanical garden played for other disciplines in the university setting. Early in the twen- 
tieth century, Roscoe Pound, another Harvard dean and promoter of what he called "sociological jurisprudence," and, a bit later, the legal realists at Columbia and Yale rejected Langdell's approach as a form of mysticism and promoted their own empirical vision of legal studies as a scientific approach to law. As Dimock carefully shows, these invocations of science have often been strikingly distant from the actual practice of the sciences. Thus Langdell invoked the logical analysis of written texts as the model of science at a time when the physical and life sciences were increasingly experimental. Even the realists, who were closer to the empirical social sciences that were emerging in the same period, ignored real differences between the normative objectives of legal argument and the descriptive practice of social science.

The exploration of the discourse of science and its appropriation in law and legal scholarship that Dimock's essay provides is crucial to the project of understanding the rise and decline of the social that we described at the beginning of this essay. Those who endeavored to provide social knowledge of law and to use law to construct and respond to social problems did so in the name of a science of society that thought it could ape the procedures and methods of the natural sciences. In turn, the movement from the social to the cultural is, in part, premised on a new imagining of science of the kind that Dimock describes, an imagining with its own misreadings of the scientific enterprise. The kind of direct, if metaphoric, traffic between legal studies and the natural sciences that Dimock engages in is justified by the need to navigate around the problematic space of the social and its claim to a scientifically knowable objectivity all its own.

It is not only law and legal scholarship, however, that has engaged in a systematic misrecognition of its relationship to science. Science also has a metaphorical relationship to law, especially in the notion of a "law of science." The standard self-description of science emphasizes the discovery of "universal laws," that is, generalizations that apply across time and place. Dimock shows that the notion of the universe as "law-abiding" is itself a highly selective gloss of the sciences. Some sciences like physics do seem to move from empirically observed regularities to the discovery of law-like rules that apply everywhere and always. Yet most scientific work may ironically be far closer to the contingent predictions that lawyers give. The life sciences especially deal with phenomena in which so many factors, including contingency, come to bear that universal laws are rarely if ever described.

What law and most of the sciences actually share is a vulnerability to diachronic processes, history and time, that the metaphorical conception of law 
in both jurisprudence and science rarely acknowledges. This may be most critical in those areas where law and science interact in practice rather than speak about each other through metaphor. Dimock develops an important example in the field of intellectual property, a field that has drawn a great deal of interest in the emergent cultural studies of law. The legal enforcement of "patents," authorized in the U.S. Constitution itself, permits successful investigators to limit access to their inventions and discoveries in a manner that can slow or even halt scientific development subject to the demands of the patent holder. Yet the idea of patentable discovery held by framers of the Constitution was far more limited than the discoveries regularly recognized by courts today.

Dimock's analysis shows what cultural studies might look like if it sought to describe and interpret the cultural exchange between practices like law and science. This would mean being attentive to the diachronic stories often implicit in the constellations of discourse and practice that students of cultural studies produce. Most scholarship, according to Dimock, attends solely to structural patterns that link developments at any time among different institutional fields. The hard work of history carried out in terrains not preordained by political categories (nation, language) is all too often left undone.

Peter Brooks looks at one particular point of contact between law and a form of scientific expertise: therapy, and especially the production of knowledge from recovered memory. Recovered memory is only the most recent of a series of flashpoints between law and what Nikolas Rose calls the "psy" experts, that go back well into the nineteenth century if not earlier. ${ }^{91}$ Indeed, it emerges at a time when, quite unlike the turn of the last century, the role of knowledge of the human psyche in the courtroom has been in general retreat. Few today would share Roscoe Pound's expectations that modern law would inevitably become a branch of human science. ${ }^{92}$

In Brooks's view, the recent trend of producing cultural analysis of law runs into the power of law to both exclude and domesticate other narratives and other forms of expertise. The recovered memory cases should be particularly troubling to law since the very facts underlying the cause of action, as in the incestuous sexual abuse of someone as a child, are produced through the work of therapy. Courts follow what Brooks considers a familiar pattern, admitting the claims while keeping out the therapeutic experts. Recovered memory gets in because it's a memory, but the only voice that should speak that memory is the subject to whom belongs, not the therapeutic discourse that produced it.

Under the banner of "common sense," psychological truth has become part of modern legal truth. The Supreme Court's confession jurisprudence, which 
Brooks has made the subject of a recent book, ${ }^{93}$ includes many psychological presumptions about what motivates subjects to confess but almost no serious discussion of the status of those theories in psychology or its fellow psy discourses. In place of critical dialogue between legal and psy expertise, there has been a series of largely metaphorical appropriations akin to those made by Dimock's academic legal theorists. This leaves law peculiarly vulnerable to cultural infection by discourses that it is not capable of recognizing as distinctive and potentially invasive. While Brooks does not provide the kind of historical examination suggested by Dimock, his discussion of confessions registers the receding role of the empirical social sciences that Greenhouse invoked with her "pragmatics" of reform. Brooks's warning that producers of cultural analysis of law should attend to how law appropriates outside analysis recalls Greenhouse's appeal for a critical engagement of social science and law with neoliberalism.

\section{Reading Legal Events}

Each of the essays in the last section of this book focuses on moments of judgment, moments in which law is asked to understand the world beyond its boundaries. Each shows law's dependence on a series of unacknowledged aesthetic, psychological, historical, and cultural assumptions. Each also reveals the power of law to produce forms of subjectivity and moments of truth, and each uses the techniques of cultural analysis and cultural studies to decode and critique the assumptions and pathways of power.

Shoshana Felman revisits one of the most contested moments of postWorld War II legality, the I957 trial of Holocaust administrator Adolf Eichmann. Turning to a trial as a crucial moment in the cultural production of law is by now a familiar mode of analysis among practitioners of cultural studies. Trials galvanize attention, call forth competing narratives, and shape meanings of basic legal categories. However, unlike many who turn to trials, Felman is explicit in her deployment of theory to read Eichmann's trial, and the theory on which she draws, psychoanalysis, is itself a source of great controversy within cultural studies of law.

Her essay focuses on a particularly searing moment of that trial /which was one of the first to be televised) to draw out its psychoanalytic resonance: the collapse-while on the stand-of a prosecution witness, Auschwitz survivor and author Yehiel Dinoor, better known as K-Zetnik la slang term meaning "concentration camp inmate"). K-Zetnik was only one of many survivors to take the 
stand and describe the Holocaust directly from the perspective of the victims; but, as Felman points out, he was also one of the few survivors whose testimony was directly relevant to Eichmann's relationship to Auschwitz. His testimony had only barely begun when in response to a set of preliminary questions about his name, K-Zetnik went into a trancelike state, fainted, and had a paralytic stroke that kept him near death in a hospital for more than two weeks.

On one level, Felman raises a question similar to the one Brooks's essay discusses: namely, how does the law respond to the trauma of violence and of recovered memory? Here, the trauma is on a scale beyond comprehension, and the problem of recovery is less one of personal recall than the capacity to communicate the truth of a historical event. Felman shows us a different face of law's relationship to trauma. Whereas Brooks's judges were mainly concerned with normalizing the testimony of recovered memory and reducing it to a legally managed fact, the Eichmann trial was meant, by the prosecutors and the judge, to produce the emotional truth of the Holocaust through its survivors. At the same time, law's demand for tight control of other discourses set real limits on the terms by which the emotion of trauma may speak. Felman ultimately reads K-Zetnik's collapse as evidence both of these limits and of the kinds of sacrifice it takes to transcend them.

While in Brooks's account the battle is primarily between the law of evidence and the knowledge that therapy produces about recovered memory, the response to the Holocaust demonstrates multiple ways that law can relate to the production of such memories. The Eichmann trial, with its deliberate invocation of the voices of the survivors, was a striking contrast to the approach taken at the earlier trial of Nazi officers conducted by the Allies in the German city of Nuremberg. The Nuremberg prosecutors, led by the American lawyers, chose to put on a documentary case that would leave the voices of the survivors out of the evidence. The Eichmann trial was quite explicitly aimed at producing survivor testimony of the Holocaust. That strategy carried real risks of failure and of delegitimizing the trial.

From this perspective, K-Zetnik's collapse marks a moment where the narrative needs of law, especially the temporality that requires locating an event in the past, ran up against the explosive presentness of trauma to the victims. ${ }^{94}$ Trials like Eichmann's are about the production of memories and the conversion of personal suffering into national memory. While legal theory has prioritized the difficulties of the judgments made at both the Nuremberg and the Eichmann trials, Felman's account reminds us that behind judgment come moments of memory that place law in far more jeopardy than somewhat abstract 
"legitimation crisis" judgments are said to entail. K-Zetnik's collapse, broadcast repeatedly over the years, produced its own cultural truth. In the end, Felman argues, the Eichmann trial succeeded as a work of legal art in allowing the muteness at the center of the Holocaust's horror to be represented in law but also as art.

Like Felman, Anthony Paul Farley draws on psychoanalysis to talk about haunting absences in legal events. Here, he explores the representations that haunt the Supreme Court's recent efforts to define the role of racial identity in the construction of constitutionally adequate voting districts. In striking down a number of black majority districts, the Court has emphasized seemingly neutral concerns like compactness but has inched precariously close to articulating a notion of whiteness underlying the body politic of the United States. Drawing on the work of Jacques Lacan, Farley probes the cultural penumbra of the implicit legal question at issue in most of these challenges: how are white people harmed by being represented by blacks? The answer lies not in the legal position of the parties but in the enduring threat that the black body poses to the imaginary coherence and power of the white body politic.

What Farley uncovers is a powerful cultural investment in black bodies as the negated bond holding white communities together. While notions of racial community are denigrated by official discourse of all sorts, and especially Supreme Court opinions, Farley finds explosive and unmistakable symbolic links between the Court's metaphysical reasoning on the shape of voting districts and the physical torture and dismemberment of blacks in the rituals of lynching. The Court's repugnance at oddly shaped districts reflects a displacement of the white community's enthusiasm for the hideous shapes produced by lynching, while their judgment reaffirms the central role of race in defining political community in the United States.

Farley's text is highly theorized and makes no claim to immediate intervention in legal struggle of the sort that Toby Miller engaged in during the NYU labor conflict; but, like Miller, Farley places relationships of power at the center of cultural studies work. Like Greenhouse and Felman, among others, he shows the great promise of the kind of interdisciplinary opening that cultural studies of law makes available. His essay provides provocative tools with which to read the law and to connect the way law is read to pervasive cultural anxieties about race and racial categories.

The final essay, by Alison Young, continues Farley's interest in the nature of legal judgment, its absences, and its haunting specters and in reading culture's anxieties. Young takes HIV and the legal cases and artistic images it gener- 
ates to interrogate the meaning of legal judgment. Young first shows how, in a variety of cases arising from attacks on gay men or efforts to expel them from the military, law depends on what she calls an "aesthetics of appearance." In these cases, law relies on the visual force of phantasy-sometimes phantasies of abuse that are used to make sense of a violent attack on a gay man, sometimes phantasies of blood uncontrollably spilling forth to justify removal of an HIVpositive soldier from military service. Through these imaginings, gay men are subject to community values in such a way as to deny them a place in the community or to devalue the place that they occupy.

Young turns to art and film to explore the "aesthetics of disappearance." These cultural artifacts refigure the image, turning it from a device used to sever relations into a bridge, connecting viewers to the bodies of gay men with HIV. She reads various works of Felix Gonzalez-Torres, an artist who died of AIDs in I 996. These works-piles of paper, spills of candy, fabric blowing in the windsuggest motion, disappearance, loss in the process of happening. Viewers, Young argues, are invited to both witness and participate in these moments. We are connected to, not severed from, the suffering of embodied, but disappearing beings. We are brought to respect alterity through a framework of judgment that brings self and other into a proximate relationship.

In Derek Jarman's film Blue, the image does not move. The camera stays fixed on a cobalt blue background as viewers hear voices, sounds, bells, poems. Jarman, who at the time he made this film was losing his eyesight to AIDs, captures and makes literal the difficulty of representing HIV, a difficulty never acknowledged in the legal cases that Young describes. In those cases, visual realism leads to a failure in legal judgment at both the aesthetic and the moral levels. "The written texts of law," Young suggests, "reconstruct the event / the 'real') of HIV in the order of vision, where judgment is governed by the desire to see, and in 'seeing,' to have done with HIv." For Young, cultural studies speaks to this failure by providing a different way of reading images and a different scene of judgment, one that can take account of the fragmented, suffering, fleshy body and help "the eye of the law ... to flicker from the mark to the pain of the other in law" by subjecting "the legal and the living to the horizon of deathbound subjectivity."

In the readings of legal events and of the flow of legal ideas into and through culture, we encounter accounts, sometimes explicit, sometimes implicit, of the power and possibilities of cultural analysis/cultural studies described in the first section of this book. These readings do not fall prey to the type of reduction of the social to the cultural that marks the politics of our era even as they 
insistently attend to the cultural basis and operation of law. They call us to attend to the cultural not for its recuperative or redemptive potential but instead to expose the layers of power that the turn to culture in the political realm often seeks to mask. They call us to the cultural as a point of departure for a critique of the epistemology and ethics that today hold out culture as the explanation and cure for problems that cannot in truth be addressed through culture itself. In the end, they remind us, like the legal realism of the past, that legal scholarship can be both critical and transformative.

\section{Notes}

I "[Q]uestions of culture ... quickly become anguished questions of identity." See Joan Scott, "Multiculturalism and the Politics of Identity," in The Identity Question 3 (John Rajchman ed., 1995).

2 Charles Taylor, Multiculturalism: Examining the Politics of Recognition (1994).

3 See Culture Wars: Opposing Viewpoints (Fred Whitehead ed., 1994).

4 For a discussion of these debates see James Hunter, Culture Wars: The Struggle to Define America (1991).

5 Theodore Caplow and Jonathan Simon, "Understanding Prison Policy and Population Trends," in 26 Crime and Justice: A Review of Research 63-120 (Michael Tonry and Joan Petersilia eds., I999); Ben J. Wattenberg, Values Matter Most (I995).

6 See Samuel Huntington, "The Clash of Civilizations," 36 International Politics (I999).

7 William Lyons, The Politics of Community Policing: Rearranging the Power to Punish (I999).

8 Nancy Ellen Rose, Workfare or Fair Work: Workfare, Welfare, and Government Work Programs (1995).

9 The recent advertising campaign for the new dollar coin is a noteworthy example of this. Who would have thought that you would need to advertise money? But, in recognizing that even currency must be given "currency," the Treasury Department discovered how much the cultural has become embedded in the economic and the political.

Io Consider the product designs and marketing of chains like Urban Outfitters and Old Navy.

I I Etienne Balibar, "Is There a 'Neo-Racism'?" in Etienne Balibar and Immanuel Wallerstein, Race, Nation, Class (1993).

I2 Jean Baudrillard, In the Shadow of the Silent Majorities, or "The Death of the Social" (1983); but see Nikolas Rose, "The Death of the Social?: Re-figuring the Territory of Government," 25 Econ. and Soc. 327-56 (1996).

I3 This movement is most widely associated with right-wing neoliberal thinking, for which the social is held to be virtually a simulacrum of government, and in which social problems are shown to disappear along with government (in theory mostly). Yet as the success of governments like those of President Clinton in the United States and Prime Minister Tony Blair in the United Kingdom has shown, the right has no monopoly on this shift. Nikolas Rose has usefully described this emerging paradigm as advanced liberalism. See Nikolas 
Rose, The Powers of Freedom (1999); Jonathan Simon, "Law After Society," 24 Law and Soc. Inquiry I 43-94 (2000).

I4 Ronen Shamir, Managing Legal Uncertainty: Elite Lawyers in the New Deal (I995); Robyn Stryker, "Rules, Resources, and Legitimacy Processes: Some Implications for Social Conflict, Order, and Change," 99 Am. J. of Sociology 847-910 (I 994).

I 5 We use the term legal studies inclusively to cover scholarly research on law and legal institutions from a variety of disciplinary perspectives, including those traditionally found in academic law schools, those associated with the social sciences-that is, political science, sociology, criminology, psychology, economics, history, and anthropology-and those rooted in the humanities - such as philosophy, rhetoric, and literature. We use the term in part because its ownership is ambiguous, sometimes being associated with particular disciplinary approaches (for example, the Journal of Legal Studies is widely associated with economic analysis of law) and sometimes with interdisciplinarity itself (a number of undergraduate majors or concentrations are titled "legal studies"|. Since we include scholarship of the most diverse sorts in this term, it may fairly be decried as doing little analytic work; yet we want to highlight the fact that all of the discourses we incorporate now share a basic anxiety about their status and thus a reflexivity about how they produce truth.

I6 Austin Sarat and Susan Silbey, "The Pull of the Policy Audience," Io Law and Policy 98 (1988).

I7 A striking example is the tradition of post-World War II empirical studies of criminal justice, much of which was funded by large corporately funded foundations and later by the government itself but which operated to expose the manifold failures of the existing institutions of justice in America. As late as the late I960s, a government commission would employ legal sociologist Jerome Skolnick to study the causes of campus and urban civil disorders, producing a volume highly critical of American institutions and government.

I8 Patricia Ewick, Robert Kagan, and Austin Sarat, "Legacies of Legal Realism: Social Science, Social Policy, and the Law," in Social Science, Social Policy, and the Law I (Patricia Ewick et al. eds., I999).

I9 Susan Silbey, "Making a Place for a Cultural Analysis of Law," I7 Law and Soc. Inquiry 39 (I992).

20 Austin Sarat, "Legal Effectiveness and Social Studies of Law: On the Unfortunate Persistence of a Research Tradition," 9 Legal Stud. Forum 23 (1985).

2 I As we use them, "interdisciplinary legal scholarship" and "legal studies" are meant to be inclusive terms covering work on law from a variety of disciplinary perspectives, including political science, sociology, criminology, psychology, economics, history, anthropology, and literature. At the same time, however, the turn to the cultural and the associated shift in logics of governance has not had a uniform impact. As a result, we attend most particularly to research in political science, sociology, criminology, and law.

22 Or to try another kind of metaphor, a software upgrade (in Jack Balkin's sense of software) to the operating system of legal studies, largely set in place during the r96os in response to the last phase of the social liberal state and its constitutional realization in the Warren Court. J. M. Balkin, Cultural Software: A Theory of Ideology (1998).

23 See Lauren Berlant, The Queen of America Goes to Washington City: Essays on Sex and Citizenship (1997). 
24 For an interesting example of this tendency, see Marjorie Garber, "Cinema Scopes: Evolution, Media, and the Law," in Law in the Domains of Culture (Austin Sarat and Thomas R. Kearns eds., I998).

Law in the Domains of Culture, supra note 24. (I998).

27 Paul Kahn, The Cultural Study of Law (I999). For a discussion of Kahn's contribution to the cultural analysis of law, see Austin Sarat, "Redirecting Legal Scholarship in Law Schools," I2 Yale J.L. and Human. I29 (2000). Balkin, supra note 22.

29 See, for example, Larry Lessig, "The Regulation of Social Meaning," 62 U. Chi. L. Rev. 943I045 (I995); Robert D. Putnam, Making Democracy Work (I993). Bryant Garth and Joyce Sterling, "From Legal Realism to Law and Society: Reshaping Law for the Last Stages of the Social Activist State," 32 Law and Soc'y Rev. 709-72 (1998); Simon, supra note I3.

By cultural programming, we mean the logics of inquiry and imagination made available within a culture at any historical juncture.

32 Critical to twentieth-century projects of governance was the control of populations both in the United States and abroad. There were (and are) clear linkages between domestic policy development and the position of the United States in the international arena. Policy and reform were geared to the production and maintenance of American power abroad.

33 On the nature of this surplus, see Margaret Montoya, "Border/ed Identities: Narrative and the Social Construction of Legal and Personal Identities," in Crossing Boundaries: Traditions and Transformations in Law and Society Research 129 (Austin Sarat et al. eds., I998).

34 For example, Ian Haney Lopez, White by Law: The Legal Construction of Race (I996), and David Delaney, Race, Place, and the Law, 1836-1948 (1998).

35 A notable example is the hostility of the U.S. Supreme Court to the discussion of global legal norms. The United States is increasingly alone among liberal systems in ignoring the force of arguments from other legal systems.

36 See John Henry Schlegel, "American Legal Realism and Empirical Social Science-I: From the Yale Experience," 28 Buff. L. Rev. 459 (1979).

37 Today, some six or seven decades later, the elite law schools remain heavily invested in this model of interaction with the social sciences despite the fact that the social sciences themselves have evolved a far more complex set of research strategies.

38 When it inevitably has to explore the space of the subject in order to address the socialpsychological motivations that underlie realist assumptions about social action, the results are far less persuasive or rigorous than the rest of the analysis. To take an influential example of a study that raises the problem of motivation and causation in legal and social change, see Gerald Rosenberg, The Hollow Hope: Can Courts Make Social Change? (1989). For an argument that this is the Achilles' heel of the project, see Jonathan Simon, "The Long Walk Home to Politics," 26 Law and Soc'y Rev. 923-42 (I992).

39 To take a well-known example that has sparked a good deal of research over the last two decades, the deployment of a new medicalized approach to defining and regulating homosexual conduct in the twentieth century, with its emphasis on deviant subjects rather than 
abhorrent acts, invested great social significance in the distinctive subjectivity of the "homosexual." See Les Moran, The Homosexual(ity) of Law (1996). The highly successful movement to protect the civil rights of gay and lesbian people grew from this investment and its certainly unintended effect of making homosexual conduct a more powerful anchor for identity. On this phenomenon, see Lisa Keen and Suzanne B. Goldberg, Strangers to the Law: Gay People on Trial (1998).

40 See, for example, Robert Ellickson, Order without Law: How Neighbors Settle Disputes (I99I).

4I Stuart Hall, "Cultural Studies: Two Paradigms," in Culture/Power/History: A Reader in Contemporary Social Theory 520-38 (Nicholas B. Dirks et al. eds., I993).

42 Id.

43 Richard Johnson, "What Is Cultural Studies Anyway?" I6 Soc. Text 38 (I986).

44 Examples of this interest are found in Alison Young, "Murder in the Eyes of the Law," I7 Stud. in Law, Politics, and Soc'y 3 I (1997); Les Moran, "From Part-Time Hero to Bent Buddy: The Male Homosexual as Lawyer in Popular Culture," I8 Stud. in Law, Politics, and Soc'y 3 (1998); and Legal Reelism: Movies as Legal Texts (John Denvir ed., I996).

45 For an exception, see Austin Sarat, "The Cultural Life of Capital Punishment: Responsibility and Representation in Dead Man Walking and Last Dance," I I Yale J.L. and Human. (I999), 153 .

46 For another analogy, see Peter Brooks, "A Slightly Polemical Comment on Austin Sarat," ro Yale J.L. and Human. 409 (I998). "In the humanities, we have seen cultural studies become a kind of hotel lobby where all disciplines can hang out, brought together by a self-satisfied discourse on the implication of knowledge with power, on the marginal and the hegemonic."

47 Carol Weisbrod, Emblems of Pluralism (2002).

48 This claim is made by Austin Sarat, "Imagining the Law of the Father: Loss, Dread, and Mourning in The Sweet Hereafter," 34 Law and Soc'y Rev. (2000) 3-46.

49 The diversity of legal realism is described by Gary Peller, "The Metaphysics of American Law," 73 Cal. L. Rev. I 152 (1985).

50 An example is the pillorying of Butler and Bhabha by a right-wing philosophy journal that awarded them a prize for unintelligibility, a story that was picked up uncritically by the news media, including NPR. See also John Leo, "Tower of Pomobabble," U.S. News and World Report, I5 March I999, at I6.

5 I The renewal of interest in realism and its meaning is itself evidence of the larger shift we discuss here. See John Henry Schlegel, American Legal Realism and Empirical Social Science (1995); American Legal Realism (William W. Fisher III et al. eds., 1993).

52 Herbert Wechsler makes this point in explaining that the Columbia of his law student days in the late r 920 s was transformed by realism even though its new dean, Young B. Smith, was the candidate of the conservatives and many of the most ardent realists had left Columbia for Yale and the new program at Johns Hopkins. See Norman Silber and Geoffrey Miller, "Toward 'Neutral Principles' in the Law: Selections from the Oral History of Herbert Wechsler," 93 Colum. L. Rev. 854, 86 I (1993).

53 An earlier version of the following pages appeared in Austin Sarat and Thomas R. Kearns, "The Cultural Lives of Law," in Law in the Domains of Culture, supra note 24. While we 
acknowledge the difficulty of disciplining the concept of culture, we do not agree with those who believe it to be analytically useless. Exemplifying such claims is the following statement from Greenblatt: "Like 'ideology' (to which, as a concept, it is closely allied) 'culture' is a term that is repeatedly used without meaning much of anything at all, a vague gesture toward a dimly perceived ethos." Stephen Greenblatt, "Culture," in Critical Terms for Literary Study 225 (Frank Lentricchia and Thomas McLaughlin eds., 1995). Or, as Mary Douglas has said about the concept of culture, "[N]ever was such a fluffy notion at large ... since singing angels blew the planets across the medieval sky or ether filled in the gaps of Newton's universe." Mary Douglas, "The Self-Completing Animal," Times Literary Supplement, 8 August $1975,886$.

54 As Rosaldo puts it, "These days questions of culture seem to touch a nerve." See Renato Rosaldo, Culture and Truth: The Remaking of Social Analysis ix (1989). See Gerald Graff, Professing Literature: An Institutional History ( 1987 ).

"The recent critics of culture in no respect comprise an internally homogeneous block, and the objections currently in play represent a complex skein of partially discrete, partially convergent influences from political economy, modernist and postmodernist anthropologies, varieties of feminist writing, cultural studies, and diverse other sources." See Robert Brightman, "Forget Culture: Replacement, Transcendence, Reflexification," Io Cultural Anthropology 509 (1995).

57 Annette Weiner notes about the discipline of anthropology and its relation to the idea of culture that "[t]oday . . . 'culture' is increasingly a prized intellectual commodity, aggressively appropriated by other disciplines as an organizing principle." Annette Weiner, "Culture and Our Discontents," 97 Am. Anthropologist 15 (I995).

58 Edward Tylor, cited by Greenblatt, supra note 53 , at 225.

59 The fashionableness in recent years of speculating about the cultural deficits of the poor and the role of liberalism in worsening them speaks to this.

60 For a particularly useful summary of these critiques, see Brightman, supra note 56 , at 509 .

6I Lila Abu-Lughod, "Writing against Culture," in Recapturing Anthropology: Working in the Present 137 (Richard G. Fox ed., 1991).

62 See Brightman, supra note 56 , at 509.

63 James Clifford, The Predicament of Culture: Twentieth-Century Ethnography, Literature, and Art 338 and 323 (1988).

64 Id., Io and I4.

65 T. M. Luhrmann, "Review of Hermes' Dilemma and Hamlet's Desire: On the Epistemology of Interpretation," 95 American Anthropologist 1058 (I 993 ).

66 See Cultural Studies (Lawrence Grossberg, Cary Nelson, and Paula Treichler eds. 1992).

67 Herbert Gans, Popular Culture and High Culture: An Analysis and Evaluation of Taste (1974).

68 See Steve Redhead, Unpopular Cultures: The Birth of Law and Popular Culture (1995).

69 Johnson, supra note 43 , at 39.

70 Id., 43.

7 I But see Stuart Hall, Chas Critcher, Tony Jefferson, John Clarke, and Brian Robert, Policing the Crisis: Mugging, the State, and Law and Order (1978).

72 Law and the Order of Culture, at vii (Robert Post ed., 1991). 
73 See Silbey, supra note r9. See also Stewart Macaulay, "Images of Law in Everyday Life: The Lessons of School, Entertainment, and Spectator Sports," 2 I Law and Soc'y Rev. I85 (I987); Anthony Chase, "Toward a Legal Theory of Popular Culture," I986 Wis. L. Rev. 527; Anthony Chase, "Historical Reconstruction in Popular Legal and Political Culture," 24 Seton Hall L. Rev. I969 (I 994); "Symposium: Popular Legal Culture," 98 Yale L.J. I 545 (I989).

74 Clifford Geertz, Local Knowledge: Further Essays in Interpretive Anthropology I84 (I983).

75 Id., 2 I8.

76 For a general discussion of the materiality of cultural life, see Raymond Williams, Problems in Materialism and Culture: Selected Essays (1980). Silbey, supra note I9, at 47.

78 Johnson, supra note 43 , at 39 .

79 Silbey, supra note I9, at $4 \mathrm{I}$.

80 Austin Sarat and Thomas R. Kearns, "Across the Great Divide: Forms of Legal Scholarship and Everyday Life," in Law in Everyday Life 3o (Austin Sarat and Thomas R. Kearns eds. I9931.

8 I Silbey, supra note I9, at 4I.

82 Peter Fitzpatrick, The Mythology of Modern Law 202 (1992).

83 Austin Sarat, " '. . . the Law Is All Over': Power, Resistance, and the Legal Consciousness of the Welfare Poor," 2 Yale J.L. and Human. 343 (I990); Michel de Certeau, The Practice of Everyday Life 37 (Steven Rendell trans., University of California Press 1984); Jon Cruz and Justin Lewis, Viewing, Reading, Listening: Audiences and Cultural Reception (1994).

84 Williams defines hegemony as "a complex interlocking of political, social, and cultural forces" that sustains particular forms of inequality and domination. See Raymond Williams, Marxism and Literature I I2 (I977). This concept, Barbara Yngvesson explains, allows us to recognize the "coexistence of discipline and struggle, of subjection and subversion, and directs attention toward a dynamic analysis of what it means to be caught up in power." Barbara Yngvesson, "Inventing Law in Local Settings: Rethinking Popular Legal Culture," 98 Yale L.J. I693 (1989).

85 Rosemary Coombe, "Contingent Articulations: A Critical Cultural Studies of Law," in Law in the Domains of Culture, supra note 24 , at 38 .

86 See Jane Gaines, Contested Culture: The Image, the Voice, and the Law (199I).

87 See Melville Nimmer and David Nimmer, Nimmer on Copyright: A Treatise on the Law of Literary, Musical, and Artistic Property and the Protection of Ideas (4 vols., 8th ed., I989); Bernard Edelman, Ownership of the Image: Elements for a Marxist Theory of Law (Elizabeth Kingdom trans., Routledge and Kegan Paul r979). See also Peter Jaszi, "Toward a Theory of Copyright: The Metamorphoses of 'Authorship' " I99 I Duke L.J. 455.

88 Rosemary Coombe, "Author/izing the Celebrity: Publicity Rights, Postmodern Politics, and Unauthorized Genders," in The Construction of Authorship: Textual Appropriation in Law and Literature IoI (Martha Woodmansee and Peter Jaszi eds., I994). See also Harold Gordon, "Right of Property in Name, Likeness, Personality, and History," 55 Northwestern U.L. Rev. 553 (1960); Joan Gross, "The Right of Publicity Revisited: Reconciling Fame, Fortune, and Constitutional Rights," 62 B.U. L. Review 986 (1982).

89 See Rosemary Coombe, supra note 85 , at $6 \mathrm{I}$.

90 The famous "maximum feasible participation" formula of the I960s "war on poverty" was 
only one instance of this pattern of federal power from the r 930 on on. See Daniel Moynihan, Maximum Feasible Misunderstanding: Community Action in the War on Poverty (I969).

9 I Nikolas Rose, Inventing Ourselves: Psychology, Power, and Personhood (I996).

Thomas Green, "Freedom and Criminal Responsibility in the Age of Pound: An Essay on Criminal Justice," 93 Mich. L. Rev. 1915-2053 (1995).

93 Peter Brooks, Troubling Confessions (2000).

94 As it happens, Felman's reading of K-Zetnik's collapse and its legal meaning clashes directly with a portion of Hannah Arendt's legendary critique of the Eichmann trial, Eichmann in Jerusalem (1964). Felman takes the opportunity to read the event through the genealogy of that earlier effort to use the trials as a window into the relationship between law and evil. Arendt was highly critical of the prosecution's whole approach in the Eichmann case, which she regarded as in many respects a "show trial." Arendt pays specific attention to K-Zetnik's collapse, which she turns into a metaphor for the wages of producing the truth of the Holocaust through its victims.

Reading Arendt psychoanalytically, Felman traces her harsh repression of the voice of the victim to Arendt's own grief for her friend Walter Benjamin's suicide while in custody at the Spanish border. Benjamin really was a victim of the banality of evil. The custody that Benjamin despaired of escaping was little more than bureaucratic bad luck at the border. By insisting that only law govern the meaning of the Holocaust, and that law avoid the risks of inviting the remembrance of violence, Arendt was excluding from the interpretation of the Holocaust what her friend Benjamin had prophetically described as "expressionless." Benjamin thought that the ability to give voice to a sense of trauma depended on a context shared between speaker and listener broad enough to encompass the trauma. Felman's analysis of Arendt reminds us that the power of law to transform the cultural meaning of events and memories, including its ability to demythologize evil, can be a political choice and not simply an inevitable expansionism in law or simply a strategy of those with the most power. 
I Approaches to the Cultural Study of Law 
